\title{
MARKETING OF PROVISION OF EDUCATIONAL TOURIST SERVICE OF THE BLACK SEA REGION IN THE CONDITIONS OF COVID-19
}

\section{МАРКЕТИНГ НАДАННЯ ОСВІТНІХ ТУРИСТИЧНИХ ПОСЛУГ У ПРИЧОРНОМОРСЬКОМУ РЕГІОНІ В УМОВАХ COVID-19}

UDC 338.48:339.138

https://doi.org/10.32843/bses.64-16

\author{
Tsviliy Sergiy \\ Candidate of Economic Sciences, \\ Associate Professor, \\ Associate Professor of Tourism, \\ Hotel and Restaurant Business \\ National University \\ «Zaporizhzhia Polytechnic» \\ Gurova Darya \\ Candidate of Geographical Sciences, \\ Associate Professor, \\ Associate Professor of Tourism, \\ Hotel and Restaurant Business \\ National University \\ «Zaporizhzhia Polytechnic»
}

\begin{abstract}
The relevance of the study is to find new ways to ensure compliance with the process of providing educational tourist services in the context of the factors of COVID-19. The modern signs of coronavirus development of universities of the Black Sea region are indicated. The fundamental issues of marketing education in tourism are identified. There is conducted a marketing study of the peculiarities of obtaining higher tourism education on the basis of studying the point of view of teachers of universities of the Black Sea region by the method of survey. A profile of the process of providing higher education for the training of specialists in the field of tourism has been compiled. Recommendations have been developed for heads of universities in order to make management decisions to improve the process of providing educational services, taking into account the factor of pedagogical potential. The conclusion is made about the effectiveness of the development of the marketing complex in ensuring the advantages of universities.

Key words: marketing, research, service, tourism, HEl, region.
\end{abstract}

Актуальность исследования заключается в поиске новых путей обеспечения соответствия процесса предоставления образовательных туристических услуг в условиях действия фракторов COVID-19. Обозначены современные признаки коронавирусного развития ВУЗов Причерноморского региона. Определены фрундаментальные вопросы маркетинга образования в туризме. Проведено маркетинговое исследование особенности получения высшего туристического образования на базе изучения точки зрения преподавателей вУзов Причерноморского региона методом опроса. Составлен профриль процесса предоставления высшего образования по подготовке специалистов в области туризма. Разработаны рекомендации руководителям ВУЗов с целью принятия управленческих решений по совершенствованию прочесса предоставления образовательной услуги с учетом фактора внутреннего педагогического потенциала. Сделан вывод о действенности разработки комплекса маркетинга в обеспечении конкурентных преимуществ ВУЗов.

Ключевые слова: маркетинг, исследование, услуга, туризм, ВУз, регион.

Актуальність дослідження полягає у пошуку нових шляхів забезпечення відповідності процесу надання освітніх туристичних послуг в умовах дії факторів пандемії COVID-19. Надано сучасні ознаки коронавірусного стану розвитку зВО Причорноморського регіону: тенденція переходу від широкої професійної до глибокої спеціалізації з універсалізацією певних модулів, що принципово змінює зміст навчання; зростання попиту на безперервну освіту за межами навчальних закладів; розробка комплексних освітніх програм для фрірм-замовників (стейкхолдерів) відносно проведення ними власної політики інтегрованої участі в процесі підготовки кваліфрікованих кадрів. Визначено базові питання маркетингу туристичної освіти, якими є: контингент, що навчається; мета та зміст навчання; термін навчання; місце розташування закладу; технологія і форми навчання, контролю та оцінки знань; склад викладачів і науковців; типи і напрямки використання навчально-методичних засобів; обсяг і структура наукової діяльності; рівень самоосвіти викладачів та студентів. Проведене маркетингове дослідження сучасних особливостей отримання туристичної освіти на основі вивчення погляду викладачів ЗВО Причорноморського регіону методом опитування. Сфрормульовано профріль процесу надання вищої освіти щодо підготовки ффахівців з туризмознавства. Розроблено рекомендації керівникам ЗВО з метою прийняття відповідних управлінських рішень з вдосконалення процесу надання туристичної освіти з урахуванням чинника внутрішнього педагогічного потенціалу: встановлення тісного практичного взаємозв'язку зВО зі стейкхолдерами; створення новітньої системи кар'єрного (адміністративного, педагогічного, наукового) розвитку; розробка програми на довго-, середньо-, короткострокові періоди щодо зміцнення матеріального становища педагогів; формування елементів сучасної організаційної культури ЗВо; організація на належному рівні якості відкритих науково-методичних, науково-практичних заходів з метою обміну досвідом й реалізації наукового потенціалу. Зроблено висновок про дієвість розробки комплексу маркетингу у забезпеченні конкурентних переваг ЗВО Причорноморського регіону відносно питань якості, ціни, іміджу, тощо.

Ключові слова: маркетинг, дослідження, послуга, туризм, ЗВО, регіон.

Formulation of the problem. Today, the priority for Ukraine as a whole and its individual regions is to build a competitive economy, which in the post-coronavirus world would be based on the model of knowledge economy where the modern education system will become a basic element. Traditionally, domestic education is a link between the labour market, human capital and the development of science and scientific infrastructure. The quality of entrepreneurship, innovation, new technologies and intellectual capital of the country depends on the quality of education. Compared to the initial period since independence, Ukraine has increased training in the field of tourism economics and tourism business, but the skills of the workforce in this area continues to decline steadily due to many problems from the migration of "best" labour resources abroad to a low level of wages in the labour market. Despite this situation, it is important for the institution of higher education, teacher, lecturer, and mentor to keep playing the central role in the training of specialists. The transition to the latest conditions for the provision of education, which are created due to the factors of COVID-19, has significantly affected the system of services in this area. All the principles of traditional education for our country (providing knowledge, students gaining practical skills, the integrity of the process of combining education and science, the desire for continuous self-improvement of employees, the image of higher education) are disintegrated; they question the effectiveness of their 
actions. The "improvement" of the education system through pseudo-consumer orientation was paid for by the loss of the quality of education, authority of teachers, integrity between competencies and student employment, students who are unable to pay for education, the reputation of most higher education institutions (HEIs). A more negative consequence is the acquisition of certain behaviour by certain students and the formation of the idea of the possibility of obtaining only a formal diploma. The tourism industry is extremely flexible in responding to the loss of quality training. In turn, full-fledged training of staff for business in the tourism sector can be provided by regional HEls, which have sufficient internal potential, close ties with partner companies and knowledge of the specifics and state of local markets. In the context of COVID-19, focusing the attention of scientists on the marketing of education in regional HEIs is a priority task now.

Analysis of recent research and publications. In the last decade, two opposite and, at the same time, related trends have emerged in the field of tourism education: firstly, education is of great importance because it is the basis of the tourism future, countries, regions and destinations, and secondly, there is a crisis. Acceleration of the transformation of the principles of quality education in Ukraine has begun in the last five years. Leading educational institutions, which have participated in various international educational projects and programmes, have contributed to this positive transformation. Features of quality tourism education have been studied constantly in different years, and recently conducted many useful studies and developed a large number of methods for transforming the education system. Wellknown scientists, such as O. Lokshyna, O. Ovcharuk, A. Kuzminskyi, etc., dealt with the issues of improving the quality of education [12;13; 15]. Problems of finding the relationship between education and employment of tourism professionals are covered in the works of scientists, teachers, practitioners, among whom the most active are S. Vitvytska, O. Kovalenko, V. Yurchenko etc. $[11 ; 21 ; 24]$. There are publications related to the quality and problems of education from the standpoint of studying the internal potential of HEIs and relevant institutions. Sufficient attention is paid to the development of education by scientists such as T. But, A. Vindyuk, D. Gurova, V. Zaitseva [25]. They note that in modern times, with characteristic changes, competition between regional HEls for students is intensifying, but not enough attention is paid to the integrated analysis of internal and external features of the process of providing educational services. The vector of development of tourist education in the Black Sea region in the coronavirus environment is considered by S. Halasyuk, O. Makarenko, L. Matviyenko, A. Mykhaylyk, S. Nezdoyminov [2; 3; 14]. The works by K. Bohomol, V. Herasymenko, O. Huri- na, I. Irtyshcheva, T. Knyazyeva, D. Krylenko, V. Tkach, M. Ohiyenko, U. Starozhylova, O. Topchiyev, V. Yavorska, S. Zakharova are focused on theoretical and practical aspects of training for the tourist market of the Black Sea region [8-10; 16-20; 23]. However, today little attention is paid to the study of the educational process from the standpoint of HEl's marketing.

Formulation of the goals of the article. The purpose of the article is to study the signs of the coronavirus conditions of the education market and, based on the analysis of the marketing potential of the Black Sea region, to develop recommendations for the leaders to make management decisions for improving the process of providing educational tourism services.

Presenting main material. In general, we can give the following signs of coronavirus development of the Black Sea region (Mykolaiv, Odesa, Kherson regions): the trend of transition from broad professional to deep specialization with the universalization of certain modules, which fundamentally changes the content of training (1); growing demand for continuing education outside educational institutions (2); development of comprehensive educational programmes for customer firms (stakeholders) to conduct their own policy of integrated participation in the modern process of training (3). Undoubtedly, certain changes in the educational process of the domestic HEIs take place in the plane of the current legislation.

Under these conditions, the right to exist is a marketing approach to market research, in particular, the vector of tourism education. In the context of the COVID-19 pandemic and the negative effects of globalization on the functioning of the domestic market of educational services, the traditional statement that demand forms supply today does not look convincing enough; this leads to the following conclusions: firstly, the ratio of supply and demand on the price and the actual volume of services provided, while in the field of higher education the offer is limited by the resource potential of HEIs, state policy, changing requirements of stakeholders; secondly, at the equilibrium price, the number of services that HEls want to offer to the market and sell to applicants does not correspond to the quantity that consumers want to buy; thirdly, in fact, in the absence of a state of equilibrium volume of production of educational services in the market, potential costs and potential shortage of the final product are possible.

The coronavirus educational space has also sharpened the attention of scientists and practitioners to distance education, which is a new promising area of HEl's marketing. HEls of the Black Sea region are already forming and offering distance educational services to the tourism market, so they play a crucial role in the formation of regional marketing in the field of tourism education and use a marketing approach 
to solving problems. However, the traditional issues of tourism education marketing remain relevant, which are: the contingent of students; purpose and content of training; training period; location of the institution; technology and forms of training, control and assessment of knowledge; composition of teachers and scientists; types and directions of use of educational and methodical means; volume and structure of scientific activity; level of self-education of teachers and students. A significant role in building the architecture of tourism education remains the internal system elements of a particular $\mathrm{HEI}$ in the region. The statistics on the basic indicators of employees of educational institutions of the Black Sea region are interesting. According to Table 1, the number of full-time employees of educational institutions in the region as of March 1, 2021 is 126,033 persons, and the average monthly salary is 10,187 UAH.

HEls of region for the provision of tourism education are presented in the Table 2.

According to Table 2, the service of tourist education is offered by nine HEls: Odesa (4), Mykolaiv (3), and Kherson (2). The study of teachers' views was conducted remotely by means of a survey method. The study was conducted in four HEls of the Black Sea region, in which there are educational programmes in the specialities 241 "Hotel and restaurant business" and 242 "Tourism" of the first (bachelor) and second (master) educational levels, namely: Odessa National Economic University, Odesa National Academy of Food Technologies, Pylyp Orlyk International Classical University, Kherson State University. A total of 60 people took part in the survey. The purpose of the study was to identify modern features of tourism education, to conduct their analysis, evaluation, to draw certain conclusions for the development of management decisions of $\mathrm{HEI}$ to improve the process of providing educational services. The relevant conditions and results of the study are presented below. According to the criterion of "teaching experience", the teachers who took part in the survey (respondents) were distributed as follows: up to 3 years (11\%), 3-5 years (9\%), 5-10 years (26\%), 10-20 years (19\%), more than 20 years (35\%). That is, only $11 \%$ of teachers with less than 3 years of teaching experience are represented, and more than half of the respondents have more than 10 years of teaching experience (54\%). This testifies to their experience, as well as the importance of professional and expert opinion of teachers. According to the criterion "teaching experience in HEl", we have the following distribution of respondents: up to 1 year (11\%), 1-3 years (14\%), $3-5$ years (28\%), more than 5 years (47\%). That is, slightly less than half of teachers have more than 5 years of work experience in HEI (47\%), and with less than 3 years of work experience in this sample only $25 \%$ of teachers are represented. This means

Table 1

Basic indicators of employees of educational institutions in the Black Sea region

\begin{tabular}{|l|c|c|c|c|c|c|}
\hline \multirow{2}{*}{$\begin{array}{c}\text { Indicators by } \\
\text { regions }\end{array}$} & $\begin{array}{c}\text { Number of full-time employees of educational } \\
\text { institutions in the region, persons }\end{array}$ & \multicolumn{2}{c|}{$\begin{array}{c}\text { Average monthly salary of employees } \\
\text { of these institutions, UAH }\end{array}$} \\
\cline { 2 - 8 } & 2021 January & 2021 February & Dev. Feb./Jan. & 2021 January & 2021 February & Dev. Feb./Jan. \\
\hline Kherson region [5] & 28,125 & 30,905 & $+2,780$ & 9,963 & 10,075 & +112 \\
\hline Mykolaiv region [7] & 34,624 & 34,584 & -40 & 9,822 & 10,259 & +437 \\
\hline Odesa region [6] & 61,805 & 60,544 & $-1,261$ & 9,873 & 10,226 & +353 \\
\hline Black Sea region & 124,554 & 126,033 & $+1,479$ & 9,886 & 10,187 & +301 \\
\hline
\end{tabular}

Table 2

HEls of the Black Sea region for the provision of tourism education [22]

\begin{tabular}{|c|c|c|c|c|}
\hline \multirow{3}{*}{ Name of higher education institution (HEI) } & Tourism & \multicolumn{3}{|c|}{ Hotel and restaurant business } \\
\hline & \multicolumn{4}{|c|}{ The level of education: } \\
\hline & first & second & first & second \\
\hline \multicolumn{5}{|l|}{ Odesa region } \\
\hline Odesa I.I. Mechnikov National University & + & + & - & - \\
\hline Odessa National Economic University & + & + & + & + \\
\hline Odesa National Academy of Food Technologies & + & + & + & + \\
\hline Izmail State University of Humanities & + & - & - & - \\
\hline \multicolumn{5}{|l|}{ Mykolaiv region } \\
\hline Pylyp Orlyk International Classical University & + & + & + & + \\
\hline Mykolayiv branch of Kyiv National University of Culture and Arts & + & - & + & - \\
\hline $\begin{array}{l}\text { Mykolayiv Interregional Institute of Human Development of the } \\
\text { Open International University of Human Development (MMIRL) }\end{array}$ & - & + & - & + \\
\hline \multicolumn{5}{|l|}{ Kherson region } \\
\hline Kherson State University & + & + & + & + \\
\hline Kherson National Technical University & + & - & + & - \\
\hline
\end{tabular}


that the majority of respondents who took part in the survey $(75 \%)$ have teaching experience in higher education exceeding three years. All teachers were asked to answer 8 questions that are to some extent related to the modern process of tourism education.

Question 1. What is the main feature of the modern pedagogical process in higher education? It was necessary to choose only one answer from the proposed: increasing the amount of study load per student (1); reducing the prestige of the teacher (2); lack of necessary motivation for students to study (3); competition with alternative educational programs (4); weak relationship between learning outcomes and career (5); another feature (specify your own) (6). The basic features of the modern pedagogical process in $\mathrm{HEl}$ are: lack of motivation for learning in students (52\%) and a weak relationship between learning and future career (29\%). Moreover, according to the authors, the second is the cause of the first. That is, we can assume that $81 \%$ of teachers are convinced that the diploma of HEI does not guarantee employment in the obtained speciality, and, therefore, is not a motive for learning and obtaining quality education.

Question 2. What attracts the work of a teacher? It was necessary to choose one option (Figure 1): capability to transfer their knowledge and experience (1); free and creative nature of the profession (2); lack of physical activity (3); good working conditions (4); material opportunities (5); social prestige (6); the ability to communicate with new people (7); broadening of horizon of their subject, the world as a whole (8).

As shown in Figure 1, the work of a teacher of disciplines in the educational direction "Tourism" today is attractive, primarily due to the free and creative nature of the profession (47\%), as well as due to the ability to transfer knowledge and experience to students (27\%).

Question 3. What qualities would you like to form in students? It was necessary to choose only one answer from the proposed ones: erudition (1); independence (2); creative approach to work (3); sociability (4); honesty (5); executive discipline (6); love of life (7); sobriety of mind, pragmatism (8); kindness, love for people (9); diligence, ability to work (10); other quality (specify your own) (11). Teachers would like to see graduate students in tourism with such acquired in HEl qualities such as: diligence, ability to work (22\%), independence (15\%), creative approach to work (20\%), and erudition (18\%). Other qualities turned out to be less important (total-25\%).

Question 4. How do you assess the existing organizational opportunities within the framework of HEI (conferences, seminars, exhibitions, webinars, online, distance courses): completely absent (1); present unsystematically - 11\% (2); partially present $16 \%$ (3); present in a significant volume - 58\% (4); present in full $-15 \%$ (5). Today, almost three out of four teachers $(73 \%)$ believe that the possibilities of HEIs of the Black Sea region allow them to organize various open scientific and methodical, scientific and practical events in the appropriate format at the appropriate level.

Question 5. Name the priority in the possibility of interesting leisure activities with the team. It was necessary to choose only one answer from the proposed ones: the prospect of creative selfexpression in professional activities (1); development of qualities and abilities that are directly related to the main job (2); implementation of organizational development projects, improvement of systems of interrelations with other divisions, faculties, departments, colleagues (3); receiving effective feedback from the management of $\mathrm{HEI}$ and colleagues regarding the results of their professional activities (4). Teachers almost equally use prospects for creative self-expression in the framework of professional activities (27\%), development of qualities and abilities (27\%) and receiving effective feedback from the management and colleagues (26\%). The least is currently used to obtain an assessment of teachers' professional activities (20\%).

Question 6. Assess the extent to which the following characteristics actually exist in $\mathrm{HEl}$ :

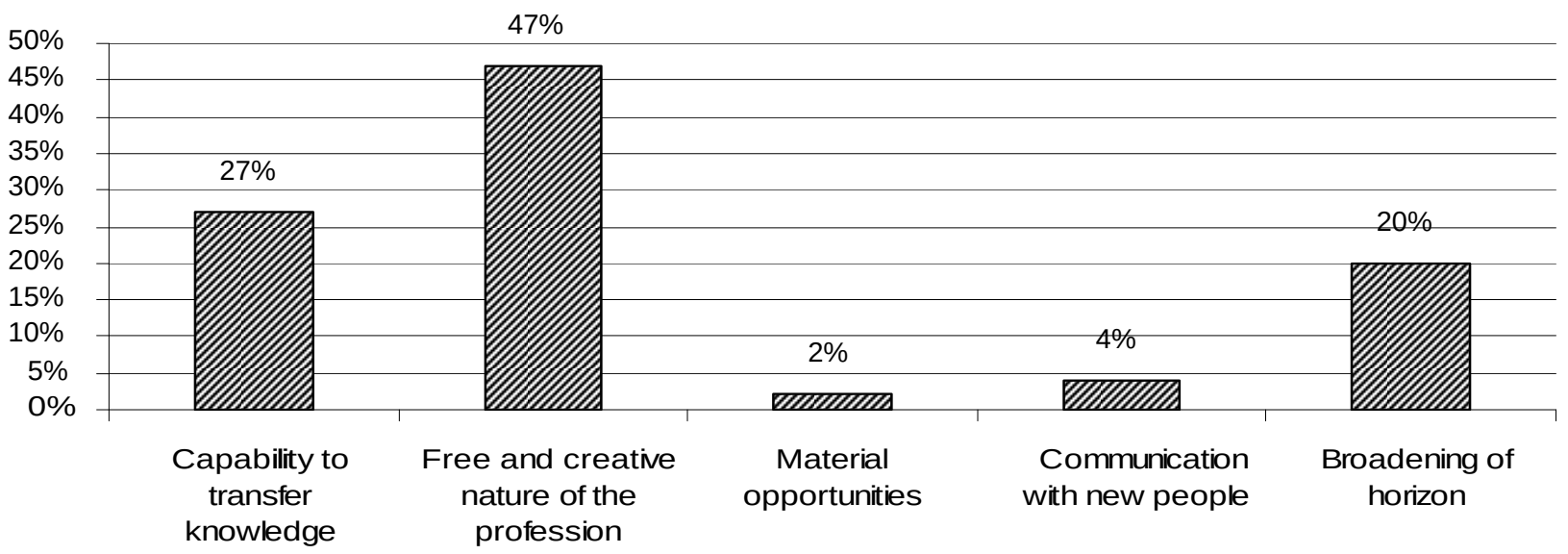

Figure 1. Attractiveness of the teacher of disciplines in the direction "Tourism" 
distinction of the best employees (1); public evaluation of specific successes (2); attention and interest to the teacher from students (3); assessment of the quality of teaching results (4); creating favourable conditions for the work of the teacher (5); assessment of the ethics of teacher's behaviour (6); creating conditions for creative growth, improving pedagogical skills (7); relationship between the volume and effectiveness of the teacher (8); transparency in the requirements and evaluation criteria (9). Respondents were asked to rate nine characteristics that are identical for a particular $\mathrm{HEI}$ on a five-level comparative scale. Teachers' answers had to fall into a certain column: completely absent, slightly present, partially present, substantially present, completely present (Table 3 ).

If one reformat the answers of respondents from Table 3 (add the critical answers "completely absent" and "completely present" in the columns of the table "slightly present" and "substantially present", respectively) and present them in a threelevel range, we obtain the following results (Table 4). This presentation gives the right to argue about the systematic implementation of a characteristic in the organization.
According to Table 4 , in the category of "relatively favourable" characteristics for HEl from the teacher's point of view are: distinction of the best employees, attention and interest to the teacher from students, assessment of the quality of teaching results, assessment of the ethics of teacher's behaviour, transparency in the requirements and evaluation criteria. The "relatively unfavourable" characteristics include: public evaluation of specific successes and the relationship between the volume and effectiveness of the teacher. In turn, the realization of the characteristic causes considerable concern: creation of conditions for creative growth, improving pedagogical skills.

Question 7. When choosing and keeping a job, what is most important for you in the psychological climate of the team? It was necessary to choose two answer options (Figure 2): the manifestation of personal qualities (1); manager's assessment (2); team relations (3); the importance of teaching (4); collective leisure (5); non-working relationship (sports sections, interest clubs, creative associations) (6).

As shown in Figure 2, for teachers, first of all, team relations are important (32\% of answers).

Table 3

Assessment of the presence of a certain characteristic in HEI

\begin{tabular}{|l|c|c|c|c|c|}
\hline \multicolumn{1}{|c|}{ Characteristics } & $\begin{array}{c}\text { Completely } \\
\text { absent }\end{array}$ & $\begin{array}{c}\text { Slightly } \\
\text { present }\end{array}$ & $\begin{array}{c}\text { Partially } \\
\text { present }\end{array}$ & $\begin{array}{c}\text { Substantially } \\
\text { present }\end{array}$ & $\begin{array}{c}\text { Completely } \\
\text { present }\end{array}$ \\
\hline Distinction of the best employees & $12 \%$ & $16 \%$ & $32 \%$ & $37 \%$ & $3 \%$ \\
\hline Public evaluation of specific successes & $7 \%$ & $23 \%$ & $33 \%$ & $32 \%$ & $5 \%$ \\
\hline $\begin{array}{l}\text { Attention and interest to the teacher from } \\
\text { students }\end{array}$ & $0 \%$ & $18 \%$ & $33 \%$ & $33 \%$ & $16 \%$ \\
\hline $\begin{array}{l}\text { Assessment of the quality of teaching } \\
\text { results }\end{array}$ & $7 \%$ & $10 \%$ & $35 \%$ & $39 \%$ & $9 \%$ \\
\hline $\begin{array}{l}\text { Creating favourable conditions for the } \\
\text { work of the teacher }\end{array}$ & $9 \%$ & $16 \%$ & $28 \%$ & $35 \%$ & $12 \%$ \\
\hline $\begin{array}{l}\text { Evaluation of the ethics of teacher's } \\
\text { behaviour }\end{array}$ & $2 \%$ & $23 \%$ & $35 \%$ & $28 \%$ & $12 \%$ \\
\hline $\begin{array}{l}\text { Creating conditions for creative growth, } \\
\text { improving pedagogical skills }\end{array}$ & $23 \%$ & $23 \%$ & $17 \%$ & $30 \%$ & $7 \%$ \\
\hline $\begin{array}{l}\text { Relationship between the volume and } \\
\text { effectiveness of the teacher }\end{array}$ & $10 \%$ & $21 \%$ & $30 \%$ & $30 \%$ & $9 \%$ \\
\hline $\begin{array}{l}\text { Transparency in evaluation requirements } \\
\text { and criteria }\end{array}$ & $7 \%$ & $18 \%$ & $24 \%$ & $33 \%$ & $18 \%$ \\
\hline
\end{tabular}

Table 4

Assessment of the presence of a certain characteristic in HEI by three-level division of answers

\begin{tabular}{|l|c|c|c|}
\hline \multicolumn{1}{|c|}{ Characteristics } & $\begin{array}{c}\text { As the system } \\
\text { is absent }\end{array}$ & Unsystematic & $\begin{array}{c}\text { As the system } \\
\text { is present }\end{array}$ \\
\hline Distinction of the best employees & $28 \%$ & $32 \%$ & $40 \%$ \\
\hline Public evaluation of specific successes & $30 \%$ & $33 \%$ & $37 \%$ \\
\hline Attention and interest in the teacher from students & $18 \%$ & $33 \%$ & $49 \%$ \\
\hline Assessment of the quality of teaching results & $17 \%$ & $35 \%$ & $48 \%$ \\
\hline Creating favourable conditions for the work of the teacher & $25 \%$ & $28 \%$ & $47 \%$ \\
\hline Assessment of the ethics of teacher's behaviour & $25 \%$ & $35 \%$ & $40 \%$ \\
\hline Creating conditions for creative growth, improving pedagogical skills & $46 \%$ & $17 \%$ & $37 \%$ \\
\hline Relationship between the volume and effectiveness of the teacher & $31 \%$ & $30 \%$ & $39 \%$ \\
\hline Transparency in the requirements and evaluation criteria & $25 \%$ & $24 \%$ & $51 \%$ \\
\hline
\end{tabular}




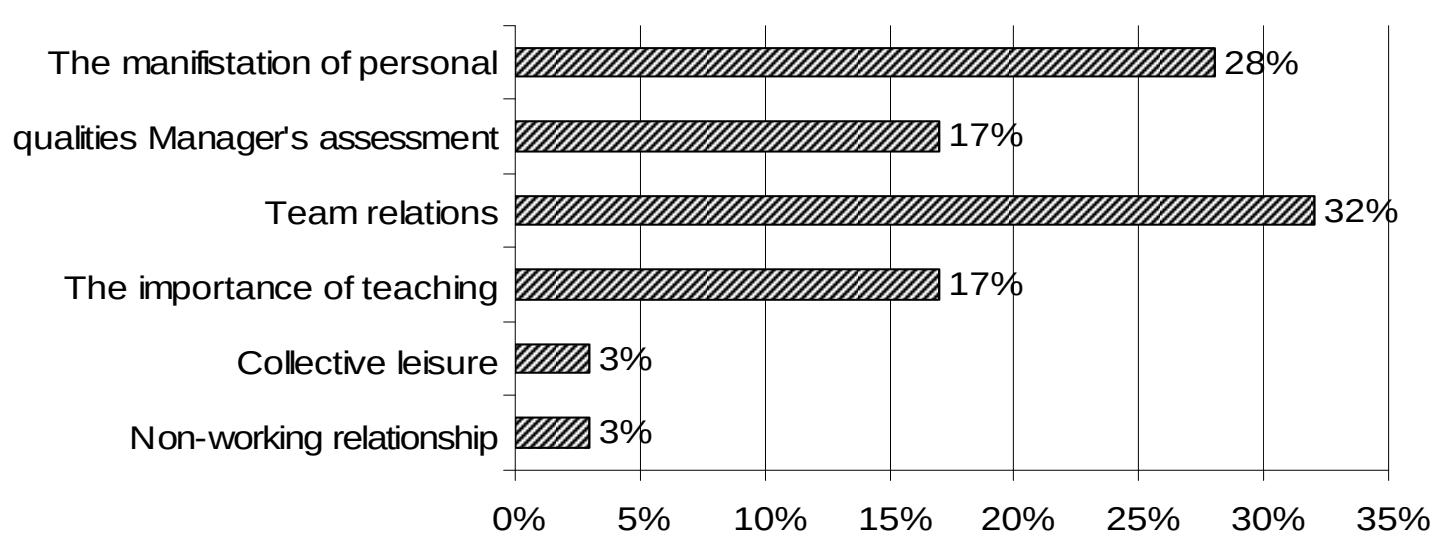

Figure 2. Assessment of the psychological climate of the team HEI

In second place in the degree of significance there is the manifestation of personal qualities: individuality and self-realization $-28 \%$. Less significant factors in assessing the psychological climate in the team for teachers were: manager's assessment (17\%) and the importance of teaching (17\%). At the same time, respondents are almost not interested in the collective leisure (3\%) and non-working relationship (3\%).

Question 8. What would be the most important for you for further successful work in HEl? It was necessary to choose only one answer from the proposed (Figure 3): teacher prestige (1); creative opportunities, removal of regulatory restrictions on teaching methods (2); material opportunities (strengthening the financial situation, the system of social guarantees, the system of life support of teachers) (3); impact on students (system of penalties and incentives) (4); access to the information (clear system of information support of the educational process, timeliness and reliability of the received information) (5); experience exchange (6); other characteristics (specify your own) (7). As shown in Figure 3 , the importance of material opportunities (the system of social guarantees, life support) was noted by $23 \%$ of teachers. 14 to $16 \%$ of responses focused on other characteristics affecting the success of further work in HEl.
In general, the results of the study allowed to form the following features (profile) of the modern process of providing higher education for the training of specialists in tourism: the specifics of the modern pedagogical process in HEI is the lack of motivation to learn from students and the weak relationship between learning and future careers (1); the attractiveness of the teacher's work lies in the ability to transfer knowledge and experience, as well as the free and creative nature of this profession (2); teachers would like to form the following qualities in students studying in the speciality "Tourism": diligence, independence, creative approach to work, education (3); the most problematic characteristic for $\mathrm{HEIs}$ of the Black Sea region is to create conditions for creative growth, improving the pedagogical skills of teachers (4); currently, the possibilities of $\mathrm{HEI}$ allow in the real and virtual space to organize at the appropriate level of various scientific and methodological, scientific and practical activities (5); teachers use joint leisure for creative self-expression and communication with colleagues, and it should be emphasized that the least currently used to assess the results of activities by the leadership of HEI (6); in the psychological climate of the team for teachers, above all, important favourable relations in the team and the possibility of self-realization as a creative person (7); the teachers noted the strengthening

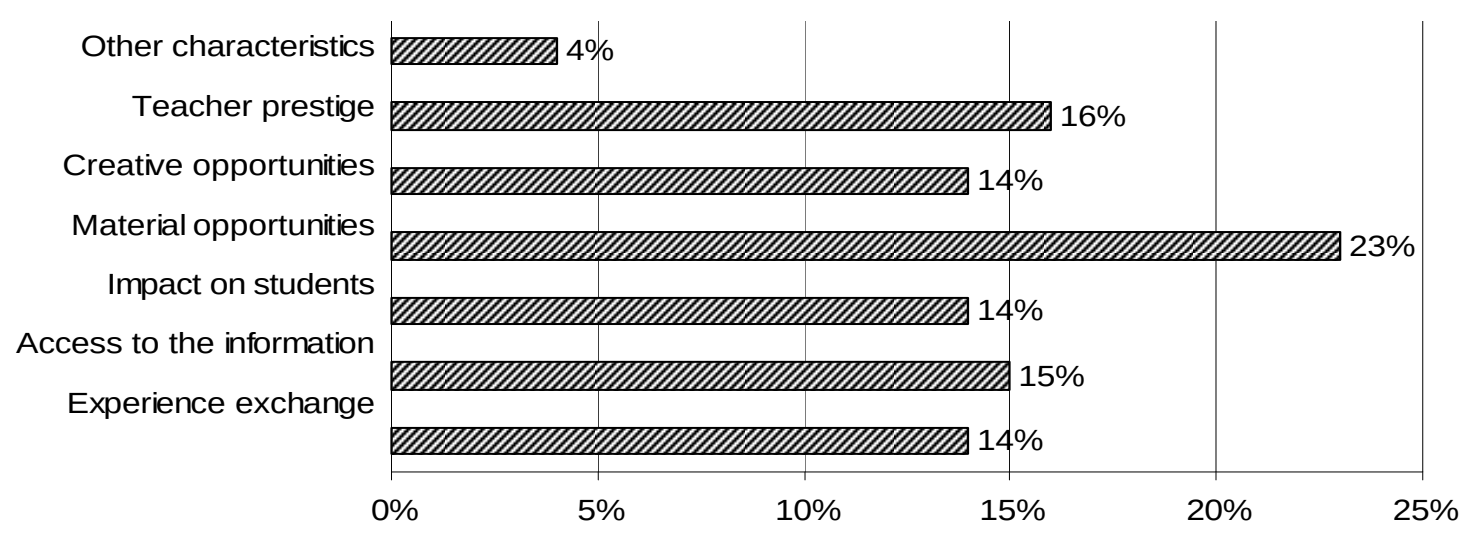

Figure 3. The most important characteristics for successful work 
of the financial situation, the system of social guarantees as important for further successful work in $\mathrm{HEI}$ (8).

These features of the profile allow to provide recommendations to the heads of HEls in order to develop appropriate management decisions to improve the process of providing tourism education, taking into account the factor of internal pedagogical potential, namely: to establish a close practical relationship between freelancers, stakeholders, and companies that are potential employers, thus restoring a direct link between the process and learning outcomes and career, which, in turn, will increase the motivation of students (1); to create a system of career (administrative, pedagogical, scientific) development in order to stimulate creative growth, improve the pedagogical skills of teachers (2); to develop programmes for long-, medium- and shortterm periods to strengthen the financial situation, the system of social guarantees, as well as the system of life support of teachers in order to increase the quality of work, primarily in the field of teaching disciplines (3); to form elements of organizational culture in $\mathrm{HEI}$, which would allow to effectively and efficiently use the free and creative nature of the teaching profession and promote their self-expression for the transfer of competencies, skills and experience to the potential of students (4); to organize at the appropriate level various in real and virtual space open scientific and methodical, scientific and practical events for the purpose of exchange of experience, realization of scientific potential and formation of knowledge at students of a tourist direction of preparation (5).

Conclusions. It is stated that in the post-coronavirus perspective only those educational institutions of the Black Sea region that have a clearly defined strategic marketing vision, which is closely related and integrated with the existing resource market orientation of $\mathrm{HEl}$, have a chance for long-term success in forming sustainable demand for tourism educational service. The content of its mission, further goals and objectives, strategic plan and decision on the development of an appropriate marketing complex depend on this. The definition of the main problems in the development of a modern complex of HEl's marketing is currently relevant to provide competitive services in the market of tourism education. We mean that the modern marketing complex contains elements: product, price, place, promotion, time, people, material evidence, process. In general, HEl's marketing complex in the Black Sea region, in which priority will be given to a balanced ratio of the above elements, can provide a post-coronavirus stable position of the educational institution in the market. An effective monitoring system will allow to find a better solution for specific tourism professionals who will be demanded by the market, the knowledge necessary for employment will be gained. In all circumstances, the monitoring system also belongs to the structures of the organization and is an information base for the development of a HEl's marketing complex, which indicates the prospects for further development in this area.

\section{REFERENCES:}

1. Derzhavna sluzhba statystyky Ukrainy [State Statistics Service of Ukraine]. ukrstat.gov.ua. Available at: http://www.ukrstat.gov.ua. (in Ukrainian)

2. Halasyuk S., Nezdoyminov S. (2019) Orhanizatsiia hotelnoho hospodarstva [Organization of the hotel industry]. Kyiv: FOP Huliaieva V.M. (in Ukrainian)

3. Halasyuk S.S., Nezdoyminov S.H. (2013) Orhanizatsiia turystychnykh podorozhei ta ekskursiinoi diialnosti [Organization of tourist trips and excursions]. Kyiv: Tsentr uchbovoi literatury. (in Ukrainian)

4. Herasymenko V. (1997) Osnovy turystskohobiznesu [Fundamentals of tourism business]. Odesa: Chornomoria. (in Ukrainian)

5. Holovne upravlinnia statystyky Khersonskoi oblasti [Main Department of Statistics of Kherson region]. (n.d.) ks.ukrstat.gov.ua. Available at: http://www.ks.ukrstat.gov.ua. (in Ukrainian)

6. Holovne upravlinnia statystyky Mykolaivskoi oblasti [Main Department of Statistics of Mykolaiv region]. (n.d.) mk.ukrstat.gov.ua. Available at: http://www.mk.ukrstat.gov.ua (in Ukrainian)

7. Holovne upravlinnia statystyky Odeskoi oblasti [Main Department of Statistics of Odesa region]. (n.d.) od.ukrstat.gov.ua. Available at: http://www.od.ukrstat. gov.ua. (in Ukrainian)

8. Hurina O.V., Ohiyenko M.M. (2018) Stratehichnyi analiz seredovyshcha rozvytku liudskoho potentsialu Prychornomorskoho rehionu [Strategic analysis of the human resources development environment of the Black Sea region]. Ekonomika $i$ suspilstvo [Economy and society], no. 15, pp. 519-527. (in Ukrainian)

9. Irtyshcheva I.O., Krylenko D.V. (2018) Instytuatsiini aspekty formuvannia modeli ekonomichnoho zrostannia Prychornomorskoho rehionu [Institutional aspects of formation of economic growth model of the Black Sea region]. Ekonomichnyy analiz [Economic analysis], no. 28, 1, pp. 62-70. (in Ukrainian)

10. Knyazyeva T.V., Bohomol K.S. (2020) Rozvytok Prychornomorskoho ekonomichnoho rehionu v konteksti mizhnarodnykh ekonomichnykh vidnosyn z krainamy Yevrosoiuzu ta Azii [Development of the Black Sea economic region in the context of international economic relations with the countries of the European Union and Asia]. Prychornomorski ekonomichni studii [Black Sea economic studies], no. 53, pp. 15-19. (in Ukrainian)

11. Kovalenko O. (2006) Stvoryty systemu yakosti vyshchoi osvity [Create a quality system of higher education]. Education of Ukraine, no. 19, p. 3. (in Ukrainian)

12. Kuzminskyi A.I. (2005) Pedahohika vyshchoi shkoly [High School Pedagogy]. Kyiv: Znannia. (in Ukrainian)

13. Lokshyna O.I. (Eds.) (2004) Monitorynh yakosti osvity: svitovi dosiahnennia ta ukrainski perspektyvy [Monitoring the quality of education: world achievements and Ukrainian prospects]. Kyiv: "K.I.S.". (in Ukrainian) 
14. Matviyenko L.P., MykhaylykA.H., Makarenko O.P. (2010) Kultura pivdennoukrainskoho rehionu. Pytannia mizhetnichnoi komunikatsii: navch. posibnyk [Culture of the southern Ukrainian region. Issues of interethnic communication: textbook.]. Mykolaiv: Vyd. Prokopchuk T.Yu. (in Ukrainian)

15. Ovcharuk O.V. (2004) Kompetentisnyi pidkhid u suchasnii osviti: svitovyi pohliad ta ukrainski perspektyvy [Competent approach in modern education: worldview and Ukrainian prospects]. Kyiv: "K.I.S.". (in Ukrainian)

16. Starozhylova U.L. (2017). Rozvytok Prychornomorskoho ekonomichnoho raionu v konteksti publichnoho upravlinnia ta yevropeiskoi intehratsii [Development of the Black Sea Economic Region in the context of public administration and European integration]. Prychornomorski ekonomichni studii [Black Sea Economic Studies], no. 21, pp. 125-131. (in Ukrainian)

17. Tkach V.O. (2011) Upravlinnia ekonomichnoiu bezpekoiu natsionalnoi ekonomiky: rehionalni aspekty zmitsnennia: monohrafiia [Management of economic security of the national economy: regional aspects of strengthening: monograph]. Dnipropetrovsk. (in Ukrainian)

18. Tkach V., Kamushkov A., Zakharova S. (2015) Rozvytok pidpryiemnytstva u sferi turyzmu: derzhavnyi ta ekonomichnyi mekhanizmy [Entrepreneurship development in the field of tourism: state and economic mechanisms.]. Teoriia ta praktyka derzhavnoho upravlinnia $i$ mistsevoho samovriaduvannia [Theory and practice of public administration and local self-government], no. 2 . Retrieved from: http://el-zbirn-du.at.ua/2015_2/20.pdf. (in Ukrainian)

19. Topchiyev O.H. (Eds.) (2012) Odeskyi rehion: peredumovy formuvannia, struktura ta terytorialna orhanizatsiia hospodarstva: navch. posibnyk [Odesa region: prerequisites for the formation, structure and territorial organization of the economy: textbook]. Odesa: Astroprint. (in Ukrainian)

20. Topchiyev O.H. (Eds.) (2018) Turystychne kraieznavstvo [Tourist local lore]. Odesa. (in Ukrainian)

21. Vitvytska S.S. (2003) Osnovy pedahohiky vyshchoi shkoly: Metodychnyi posibnyk dlia studentiv mahistratury [Fundamentals of higher school pedagogy: A guide for graduate students]. Kyiv: Tsentr navchalnoi literatury. (in Ukrainian)

22. VNZ Ukrainy [HEls of Ukraine]. osvita.ua Available at: https://ua.osvita.ua/vnz/guide/sea-rch17-0-0-70-0.html. (in Ukrainian)

23. Yavorska V.V. (2018) Orhanizatsiia i menedzhment turyzmu: navchalnyi posibnyk [Organization and management of tourism: a textbook]. Odesa: Vyd-vo "Druk pivden"'. (in Ukrainian)

24. Yurchenko V.I. (1997) Optymizatsiia vzaiemozviazku u systemi «student-vykladach» [Optimizing the relationship in the "student-teacher" system]. Kyiv. (in Ukrainian)

25. Zaitseva V.M., But T.V., Gurova D.D. (2018). Turystski resursy Ukrainy: Navchalny posibnyk dlia studentiv HEI [Tourist resources of Ukraine: Textbook for students of higher educational institutions]. Zaporizhzhia: "Prosvita". (in Ukrainian)

\section{БІБЛІОГРАФІЧНИЙ СПИСОК:}

1. Державна служба статистики України. URL: http://www.ukrstat.gov.ua/ (дата звернення: 28.02.2021).
2. Галасюк С., Нездоймінов С. Організація туристичних подорожей та екскурсійної діяльності. Київ: Центр учбової літератури, 2013. 178 с.

3. Галасюк С.С., Нездоймінов С.Г. Організація готельного господарства. Київ: ФОП Гуляєва В.М., 2019. 204 c.

4. Герасименко В.Г. Основи туристського бізнесу : навчальний посібник. Одеса : Чорномор'я, 1997. 160 с.

5. Головне управління статистики Херсонської області. URL: http://www.ks.ukrstat.gov.ua/ (дата звернення: 07.04.2021).

6. Головне управління статистики Миколаївської області. URL: http://www.mk.ukrstat.gov.ua/ (дата звернення: 07.04.2021).

7. Головне управлянні статистики Одеської області. URL: http://www.od.ukrstat.gov.ua/ (дата звернення 07.04.2021).Коваленко О. Створити систему якості вищої освіти. Освіта України. 2006. № 19.

8. Гуріна О.В., Огієнко М.М. Стратегічний аналіз середовища розвитку людського потенціалу Причорноморського регіону. Економіка і суспільство. 2018. Вип. 15. С. 519-527.

9. Іртищева І.О., Криленко Д.В. Інстутаційні аспекти фрормування моделі економічного зростання Причорноморського регіону. Економічний аналіз. 2018. T.28. № 1. С. 62-70.

10. Князєва Т.В., Богомол К.С. Розвиток Причорноморського економічного регіону в контексті міжнародних економічних відносин 3 країнами Євросоюзу та Азії. Причорноморські економічні cmyдiï. 2020. В. 53. C. 15-19.

11. Коваленко О. Створити систему якості вищої освіти. Освіта України. 2006. № 19. С. 3.

12. Кузьмінський А.І. Педагогіка вищої школи : навчальний посібник. Київ : Знання, 2005. 486 с.

13. Моніторинг якості освіти: світові досягнення та українські перспективи / за заг. ред. О.І. Локшиної. Київ : "К.І.С.", 2004. 128 с.

14. Матвієнко Л.П., Михайлик А.Г., Макаренко О.П. Культура південноукраїнського регіону. Питання міжетнічної комунікації : навч. посіб. / за заг. ред. А.Г. Михайлика. Миколаїв : Вид. Прокопчук Т.Ю., 2010. 322 c.

15. Компетентісний підхід у сучасній освіті: світовий погляд та українські перспективи / під заг. ред. О.В. Овчарук. Київ : «К.І.С.», 2004. 112 с.

16. Старожилова У.Л. Розвиток Причорноморського економічного району в контексті публічного управління та європейської інтеграції. Причорноморські економічні студії. 2017. Вип. 21. С. 125-131.

17. Ткач В.О. Управління економічною безпекою національної економіки: регіональні аспекти зміцнення : монограсрія. Дніпропетровськ, 2011. $364 \mathrm{c}$.

18. Ткач В., Камушков А., Захарова С. Розвиток підприємництва у сорері туризму: державний та економічний механізми. Теорія та практика державного управління і місцевого самоврядування. 2015. № 2 URL: http://el-zbirn-du.at.ua/2015_2/20.pdf (дата звернення: 28.03.2021).

19. Топчієв О.Г. Одеський регіон: передумови формування, структура та територіальна організація господарства: навч. посібник/ за ред. О.Г. Топчієва. Одеса : Астропринт, 2012. 336 с. 
20. Топчієв О.Г. Туристичне краєзнавство. Одеський туристичний регіон : навчальнометодичний посібник / за ред. О. Г. Топчієва. Одеса, 2018. 190 с.

21. Вітвицька С.С. Основи педагогіки вищої школи : методичний посібник для студентів магістратури. Київ : Центр навчальної літератури, 2003. 316 с.

22. ВНЗ України. URL: https://ua.osvita.ua/vnz/guide/search-17-70-0.html (дата звернення: 28.03.2021).
23.Яворська В.В. Організація і менеджмент туризму : навчальний посібник. Одеса: Вид-во «Друк південь», 2018. 218 с.

24. Юрченко В.І. Оптимізація взаємозв'язку у системі «студент-викладач». Київ, 1997. 110 с.

25. Зайцева В.М., Бут Т.В., Гурова Д.Д.. Туристські ресурси України : навч. посібник для студентів ВНЗ. Запоріжжя : TOB РВА «Просвіта», 2018. 312 с. 